\section{Wild Resource Diversity of Mytilus unguiculatus Reduced by Aquaculture in the Southeast China Sea}

\author{
Yahong Guo ${ }^{1,3}$, Zeqin $\mathrm{Fu}^{1,3}$, Jiantong Feng ${ }^{1,3}$, Chengrui Yan ${ }^{1,3}$, Yingying Ye, ${ }^{1,3 *}$, \\ KaidaXu² and Baoying Guo ${ }^{1,3}$ \\ ${ }^{1}$ National Engineering Research Center for Marine Aquaculture, Marine Science and \\ Technology College, Zhejiang Ocean University, No.1 Haida South Road, Changzhi \\ Island, Zhoushan, Zhejiang, 316022, PR. China \\ ${ }^{2}$ Scientific Observing and Experimental Station of Fishery Resources for Key Fishing \\ Grounds, MOA, Key Laboratory of Sustainable Utilization of Technology Research, \\ Marine Fisheries Research Institute of Zhejiang, Zhoushan 316021, PR China \\ ${ }^{3}$ Key Laboratory of Informatization of Habitat Monitoring and Fishery Resource \\ Conservation Research in the East China Sea of Zhejiang Province, Zhejiang Ocean \\ University, Zhoushan 316021, PR China
}

\begin{abstract}
A B S T RA C T
The hard-shelled mussel, Mytilus unguiculatus, is one of main aquaculture bivalve species in Southeast China Sea, and excellent growth characteristics. For mussel breeding, farmers use wild individuals to multiply the cultured populations. However, blind selection of wild parents has inevitably resulted in inbreeding and decreased genetic variation. In this study, four wild specimens groups (ZSW, WZW, $\mathrm{NNW}$, and FZW) and four cultured specimens groups (ZSC, WZC, NDC, and FZC) of M. unguiculatus were used to analyze their genetic diversity, population structure and understand the relationship between the wild and cultured specimens groups. The results showed that haplotype diversity $(h)$ of the cultured specimens groups (from 0.621 to 0.797 ; average, 0.717) was higher than that of three wild specimens groups (ZSW, WZW, and NNW; from 0.428 to 0.668 ; average, 0.560 ). The pairwise $F_{\mathrm{ST}}$ values suggested that only the FZW sample showed significant divergence from the others. The wild and cultured ZS and WZ specimens groups were similar, and the wild and cultured ND specimens groups were crossed. Thus, we need to establish genetic protection units for M. unguiculatus, limit the selection of breeding parents, and maintain a high-quality germplasm bank for M. unguiculatus.
\end{abstract}

\begin{tabular}{l} 
Article Information \\
\hline Received 15 October 2019 \\
Revised 02 January 2020 \\
Accepted 28 January 2020 \\
Available online 16 June 2021 \\
Authors' Contribution \\
\hline YY conceived and designed the \\
experiments. YG, ZF, JF and CY \\
performed the experiments. YY and \\
KX analyzed the data. BG provided \\
analysis tools. YY wrote the paper. YG \\
and JF collected field material and \\
processed the samples. \\
Key words \\
\hline Mytilus unguiculatus, Genetic \\
variation, Aquaculture, Genetic \\
protection unit, 16S rRNA
\end{tabular}

\section{INTRODUCTION}

$\mathrm{T}$ he hard-shelled mussel, Mytilus unguiculatus, is one of the four main economic bivalve used in the aquaculture industry in China. It has a wide distribution in the coast of Japan, Korea, and China (Shen et al., 2009). In China, M. unguiculatus is distributed in the temperate coastal zone from the Bohai Sea to the East China Sea. It is one of the main aquaculture mollusk species in Zhejiang Province, Shandong Province, Jiangsu Province and Fujian Province (Chang et al., 2007). The dried visceral mass is used in traditional food therapy and recorded in Materia Medica. Although attempts have been made to improve its breeding, the natural resources of $M$. unguiculatus are decreasing because of commercial exploitation. In previous

\footnotetext{
* Corresponding author: yeyy@zjou.edu.cn 0030-9923/2021/0005-1669 \$ 9.00/0

Copyright 2021 Zoological Society of Pakistan
}

studies, M. unguiculatus was selected as an ecotoxicology model to monitor marine pollution in China (Wang et al., 2010; Xu et al., 2016; Yang et al., 2014). Yang et al. (2015) suggested that the wild resources are under the risk of depletion around Taishan Islands in Fujian Province. Yuan et al. (2017) assessed the resources of Yushan Island using $C O I$ and suggested that the divergence of samples from those in five other locations was low and only the Yushan sample showed differentiation. Because of limited information on the genetic resources of $M$. unguiculatus, it is difficult to set a genetic baseline for mussel aquaculture.

For genetic conservation, the adaptive potential of a population is correlated with the phenotypic variation of genes (Hoffmann and Sgrò, 2011). In natural populations, inbreeding and gene drift result in neutral genetic variation and reduce their viability (O'grady et al., 2006). For an effective population size, neutral genetic diversity could show the long-term potential of evolution and species adaptability (Kahilainen et al., 2014; Reed and Frankham, 
2001). Thus, estimation of the genetic variation between wild and cultured samples is useful for establishing a genetic protection unit for wild populations (Xiong et al., 2014). Protection of the genetic diversity of wild populations and separation of wild and farmed communities are necessary to maintain a good gene stock for the breeding industry. Vigorous development of mussel aquaculture had led to the invasion of the habitats of wild populations by the cultured stock, and the genetic diversity of the wild populations and potential for evolution and adaptability have decreased. A decrease in genetic variation would affect the quality of germplasm resources.

Molecular markers are widely used to identify species and measure interspecific and intraspecific genetic divergence. Because the oceans lack sufficient genetic barriers, it is easy for marine species to exchange genes material (Palumbi, 1994). The 16S rRNA gene is a commonly used molecular marker (Rochelle et al., 1992) that can provide sufficient evolutionary information to confirm the phylogenetic relationships of both close and distant species, and it has been used in many studies of aquatic organisms (An et al., 2005; Thanh et al., 2015; Pan et al., 2006).

In this study, the $16 \mathrm{~S}$ rRNA gene was used to analyze wild and cultured specimens groups of $M$. unguiculatus along the southeast coastal areas of China and obtain basic evolutionary information on the phylogenetic relationships of both wild and cultured $M$. unguiculatus and accumulate raw genetic data for establishing a genetic baseline. We hope that this study would provide insight for establishing a genetic protection unit for M. unguiculatus and maintaining a high-quality genetic resource base for breeding and fisheries management.

\section{MATERIALS AND METHODS}

\section{Specimen collection}

A total of 157 wild and cultured specimens were collected from four locations: Zhoushan, Wenzhou, Ningde, and Fuzhou. The wild specimen groups were named ZSW, WZW, NNW, and FZW, and the cultured specimen groups, ZSC, WZC, NNC, and FZC. The sampling details are shown in Table I and Figure 1. The mussel individuals were applied morphological identification and the adductor muscle was dissected and stored in $100 \%$ alcohol until DNA extraction.

DNA extraction was performed using the improved salting-out method reported by Aljanabi et al. (1997). The DNA quality was tested using $2 \%$ agarose gel electrophoresis. The DNA concentration was evaluated with the NanoDrop 2000 Spectrophotometer (Thermo Fisher Scientific, MA, USA) at an absorption ratio of
$260 / 280 \mathrm{~nm}$. Then, the DNA was diluted to a concentration of $40-60 \mathrm{ng} / \mu \mathrm{l}$ and stored at $-20^{\circ} \mathrm{C}$.

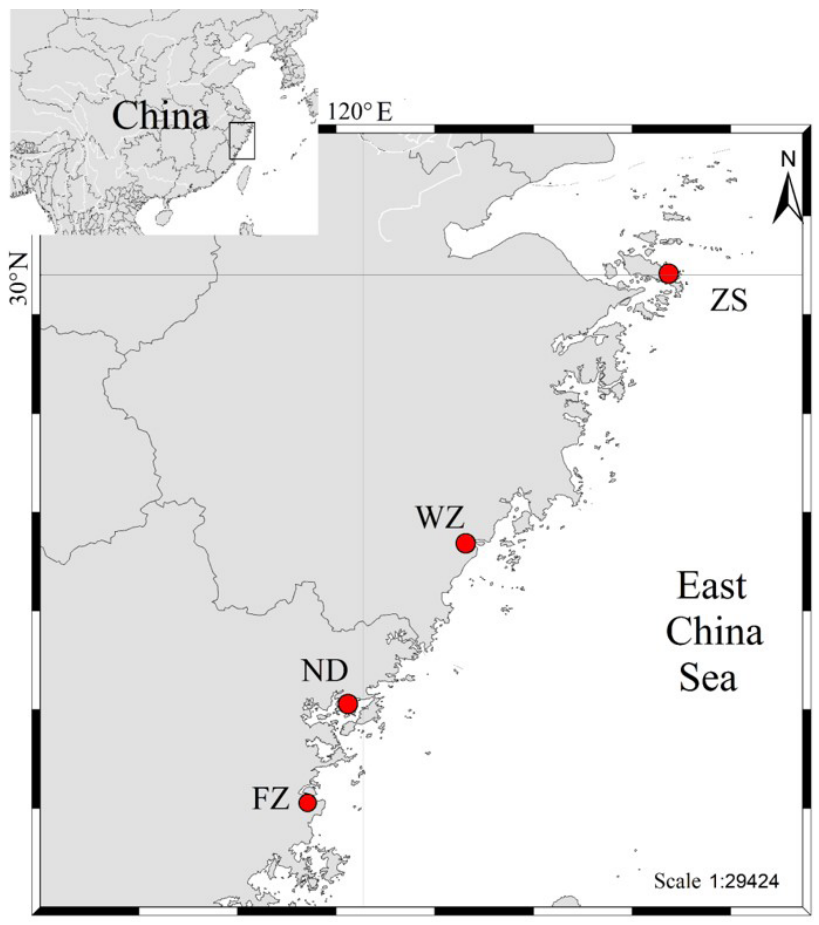

Fig. 1. The map shows the sampling locations in the East China Sea.

\section{Design and sequencing of the 16S rRNA gene}

The mitochondrial (mt)-DNA sequences of $M$. unguiculatus were used for amplifying fragments of the 16S rRNA gene by using the primers $16 \mathrm{~S} 3 \mathrm{~L}$, 5'-TGAGCGTGCTAAGGTAGC-3', and 16S4H, 5'-AGCCAACATCG AGGTCGC-3' (Lydeard et al., 1996). The PCR volume was $25 \mu \mathrm{l}$, containing $2.5 \mu \mathrm{l}$ of $10 \times$ buffer, $2 \mu \mathrm{lof} \mathrm{Mg}^{2+}(20 \mathrm{mmol} / \mathrm{l}), 2 \mu \mathrm{l}$ of dNTPs $(2.5 \mathrm{mmol} / \mathrm{l}), 0.2$ $\mu \mathrm{l}$ of Taq DNA polymerase (5 U/ $\mu \mathrm{l}), 1 \mu \mathrm{l}$ of the template DNA, $1 \mu \mathrm{l}$ of each forward and reverse primer, and $16.3 \mu \mathrm{l}$ of $\mathrm{ddH}_{2} \mathrm{O}$. The reactions were performed at $94^{\circ} \mathrm{C}$ for $2 \mathrm{~min}$, followed by 35 cycles of $94^{\circ} \mathrm{C}$ for $1 \mathrm{~min}, 52^{\circ} \mathrm{C}$ for $30 \mathrm{~s}$, and $72^{\circ} \mathrm{C}$ for $1 \mathrm{~min}$ and $72^{\circ} \mathrm{C}$ for $10 \mathrm{~min}$. The PCR products were obtained using $1.5 \%$ agarose gel electrophoresis. The sequencing was performed by Shanghai Invitrogen Biotechnology Co. Ltd., Shanghai, China.

\section{Sequence analysis}

The DNA fragment was assembled using ClustalX v2.1 (Larkinetal.,2007). Foridentifying the species and fragment positions, all fragments were compared using BLAST (https://blast.ncbi.nlm.nih.gov/Blast.cgi). The software MEGA v7.0 was used to align the fragments and perform 
Table I. Sampling details for the wild and cultured specimens of Mytilus unguiculatus.

\begin{tabular}{llllllll}
\hline Samples & Sampling date & Latitude, longitude & N & n & np & h & $\boldsymbol{\pi}$ \\
\hline ZSC & Oct. 2010 & $123^{\circ} 25^{\prime} \mathrm{E} 30^{\circ} 32^{\prime} \mathrm{N}$ & 18 & 6 & 2 & $0.745 \pm 0.079$ & $0.0042 \pm 0.0009$ \\
ZSW & Oct. 2010 & $123^{\circ} 25^{\prime} \mathrm{E} 30^{\circ} 32^{\prime} \mathrm{N}$ & 20 & 5 & 3 & $0.668 \pm 0.097$ & $0.0033 \pm 0.0007$ \\
WZC & Oct. 2010 & $120^{\circ} 25^{\prime} \mathrm{E} 27^{\circ} 33^{\prime} \mathrm{N}$ & 18 & 3 & 0 & $0.621 \pm 0.067$ & $0.0024 \pm 0.0004$ \\
WZW & Oct. 2010 & $120^{\circ} 25^{\prime} \mathrm{E} 27^{\circ} 33^{\prime} \mathrm{N}$ & 26 & 3 & 1 & $0.428 \pm 0.095$ & $0.0015 \pm 0.0004$ \\
NNC & July 2009 & $119^{\circ} 25^{\prime} \mathrm{E} 26^{\circ} 34^{\prime} \mathrm{N}$ & 18 & 8 & 6 & $0.797 \pm 0.074$ & $0.0114 \pm 0.0028$ \\
NNW & July 2009 & $119^{\circ} 25^{\prime} \mathrm{E} 26^{\circ} 35^{\prime} \mathrm{N}$ & 20 & 7 & 4 & $0.584 \pm 0.127$ & $0.0047 \pm 0.0000$ \\
FZC & Dec. 2010 & $119^{\circ} 52^{\prime} \mathrm{E} 26^{\circ} 03^{\prime} \mathrm{N}$ & 17 & 6 & 3 & $0.706 \pm 0.106$ & $0.0032 \pm 0.0007$ \\
FZW & Dec. 2010 & $119^{\circ} 52^{\prime} \mathrm{E} 26^{\circ} 03^{\prime} \mathrm{N}$ & 20 & 14 & 11 & $0.916 \pm 0.055$ & $0.0508 \pm 0.0100$ \\
Total & & & 157 & 33 & & $0.694 \pm 0.033$ & $0.0116 \pm 0.0027$ \\
\hline
\end{tabular}

the model test (Kumar et al., 2016). DnaSP v6.0 was performed to group and define the haplotypes and estimate the following genetic parameters: $N$, number of individuals; $n$, number of haplotypes; $n p$, number of private haplotypes; $h$, haplotype diversity; and $\pi$, nucleotide diversity (Rozas et al., 2017). All the fragments were analyzed using the software Arlequin v3.5 (Excoffier and Lischer, 2010; Excoffier et al., 1992), and all fragments (using the GTR model, $+\mathrm{G}=0$ ) were subjected to hierarchical analysis of molecular variance (AMOVA); the pairwise $F_{\mathrm{ST}}$ values were calculated with 10,000 permutations. The formula $F_{\mathrm{ST}}=1 /\left(4 N_{m}+1\right)$ was used to calculate the number of migrants $\left(N_{m}\right)^{m}$. An unweighted pair group method with arithmetic mean (UPGMA) tree was constructed on the basis of the pairwise genetic distances by using MEGA v7.0 with 1,000 bootstrap values (Kumar et al., 2016). A heatmap of $F_{\mathrm{ST}}$ and $N_{m}$ with the UPGMA tree was plotted using the $\mathrm{R}$ program. The plot for mismatch distribution was constructed using the software DnaSP v6.0 (Rozas et al., 2017). Network v5.1 was used to construct the haplotype network (Röhl and Mihn, 1997).

To evaluate the genetic divergence between each location, the fragment data were converted from FASTA to STR format. Using the package GenAlEx v6.5, principal coordinate analysis (PCoA) was performed on the basis of the genetic distance between populations (Peakall and Smouse, 2006). The software STRUCTURE v2.3.4 was used to cluster the samples (Evanno et al., 2005). Twenty replications were performed using the admixture model, correlated allele frequencies and the prior population information with a burn-in period of 100,000 followed by $1,000,000$ iterations and $K=1-8$. The most suitable $K$ value was determined using the statistical $\Delta K$ with STRUCTURE HARVESTER v0.6.92 (Earl et al., 2011). The software CLUMMP v1.1.2 (Jakobsson et al., 2007) was used to summarize parameters across 20 runs, and the website "POPHELPER (www.pophelper.com)" was used to acquire the line chart for each $K$ value and the population structure plot for the best $\Delta K$.

\section{RESULTS}

\section{Genetic diversity}

A 303-bp fragment of the 16S rRNA gene was analyzed and 33 haplotypes (Genbank under accession numbers: MG888480-MG888512) were obtained from 157 specimens groups of $M$. unguiculatus. The sampling size and genetic parameters of each specimen are listed in Table I.

The number of haplotypes $(n)$ was between 3 (WZC) and 14 (FZW). The number of private haplotypes was between 0 (WZC) and 11 (FZW). Hap3 was the highfrequency haplotype and observed in all specimens groups, accounting for $50.32 \%(79 / 157)$ of the total haplotypes identified (Fig. 2). Hap2 and hap3 were detected in most specimens groups, accounting for $73.25 \%$ (115/157) of the total haplotypes. The haplotype $(h)$ and nucleotide $(\pi)$ diversity were $0.428 \pm 0.095$ (WZW) to $0.916 \pm 0.055$ $(\mathrm{FZW})$ and $0.0015 \pm 0.0004$ (WZW) to $0.0508 \pm 0.0100$ (FZW), respectively.

\section{Genetic structure}

The pairwise $F_{\mathrm{ST}}$ values ranged from -0.009 to 0.216 , and $N_{m}$ ranged from 1.22 to 384.87 (Fig. 3). AMOVA (Table II) showed that $13.94 \%$ of the genetic variation was observed among populations, and the genetic difference within populations explained $86.06 \%$ of the total variation. For the fixation index, $F_{\mathrm{ST}}$ value was 0.139 (Table II). According to Nei's standard genetic distance, the eight populations were gathered into two clusters (Fig. 4). The $K$ values were estimated and $\Delta K=2$ (Fig. 4). In the UPGMA tree of the haplotypes (Fig. 2), FZW had the highest number of private haplotypes. The plot of the haplotype network (Fig. 5) showed that these haplotypes were gathered into 
one cluster. PCoA (Fig. 6) indicated FZW had diverged from the others. The estimation of genetic structure also showed that FZW had diverged from the other samples. Except for FZW, the seven specimens groups showed nonsignificant divergence.

Table II. AMOVA for the eight location specimens of Mytilus unguiculatus.

\begin{tabular}{lllll}
\hline Source of variation & d.f. & $\begin{array}{l}\text { Sum of } \\
\text { squares }\end{array}$ & $\begin{array}{l}\text { Variance } \\
\text { components }\end{array}$ & $\begin{array}{l}\text { \% of } \\
\text { variation }\end{array}$ \\
\hline Among populations & 7 & 44.82 & 0.25 & $13.94 \%$ \\
Within populations & 149 & 228.69 & 1.53 & $86.06 \%$ \\
Total & 156 & 273.51 & 1.78 & \\
Fixation Index & & & $F_{\mathrm{ST}}$ & $0.139 * *$ \\
\hline$* * P<0.01$ & & & &
\end{tabular}

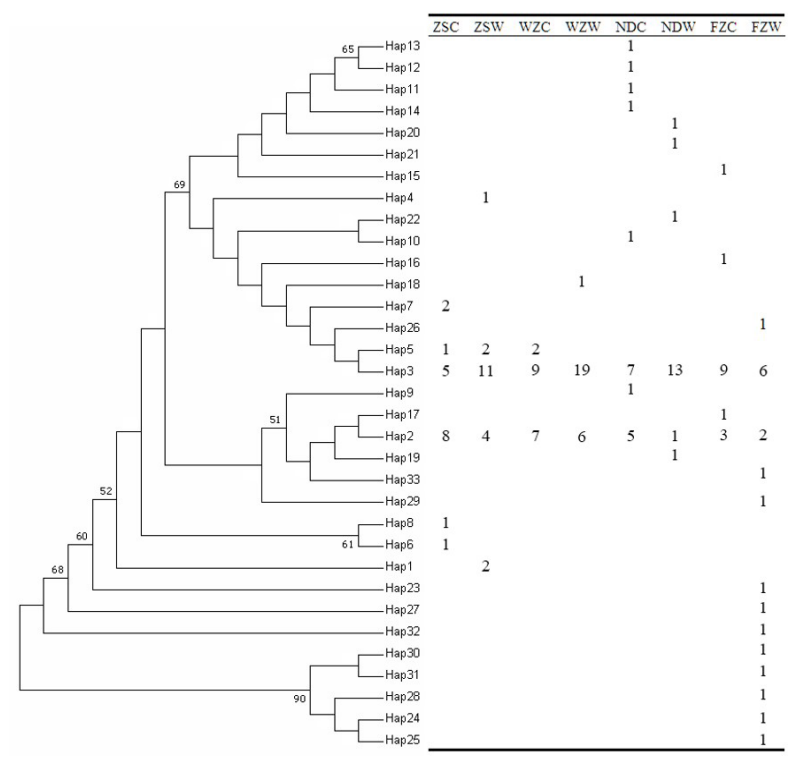

Fig. 2. UPGMA tree of 33 haplotypes of the $16 \mathrm{~S}$ rRNA gene and the number of haplotypes of the eight specimens groups.

\section{DISCUSSION}

Genetic diversity between specimens groups

The haplotype diversity of the cultured specimens (from 0.621 to 0.797 ; average, 0.717) was higher than that of three wild specimens groups (ZSW, WZW, and NNW; from 0.428 to 0.668 ; average, 0.560). Expect for FZW, the wild specimens showed non-significant genetic diversity. Both haplotype and nucleotide diversities were low. The mtDNA diversity was significantly reduced in the cultured specimens groups; this has been observed in other fish and mussel aquaculture species (Shu et al., 2008; Lundrigan et al., 2005). With human intervention, the cultured specimens groups expanded from a small number to several successful breeders, which is analogous to a previous occurrence of a bottleneck in a population of M. unguiculatus (Allendorf, 1986). Furthermore, to reduce the production cost, most mollusk farmers collect the natural spat from wild populations of M. unguiculatus. This may be why the haplotype number of the cultured specimens groups was less than that of the wild specimen groups.

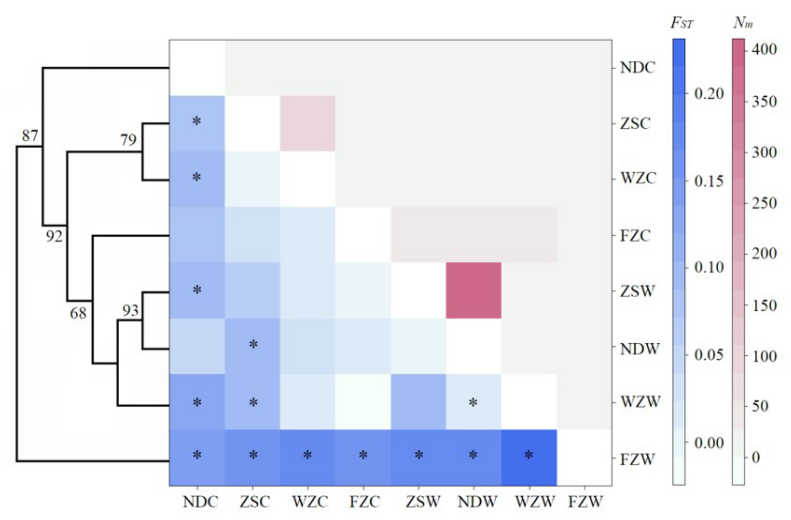

Fig. 3. Heatmap of FST and Nm with the UPGMA tree for the eight specimens groups. The pairwise $F_{S T}$ values ranged from -0.009 to 0.216 , and $N_{m}$ ranged from 1.22 to 384.87 .

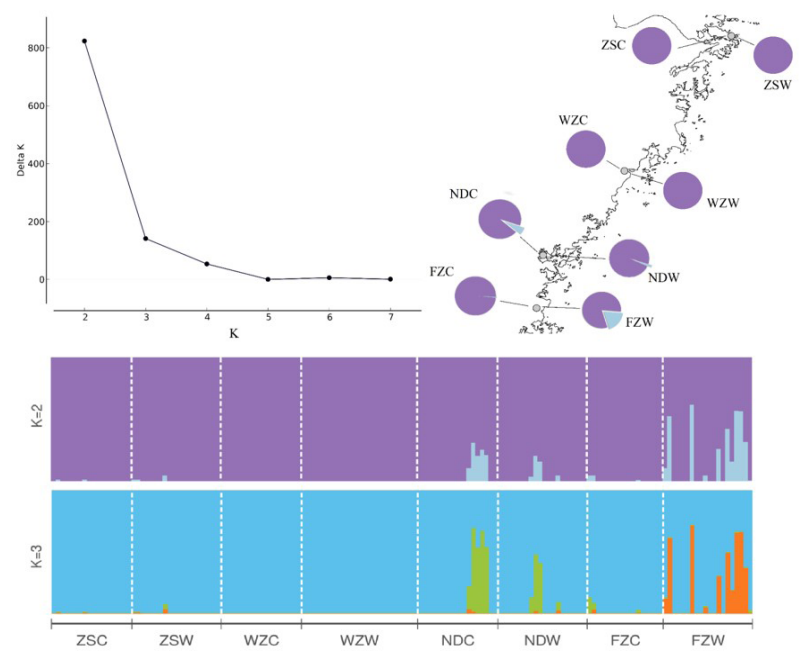

Fig. 4. STRUCTURE analysis for the 16S rRNA of Mytilus unguiculatus.

Genetic structure among the specimens groups

The AMOVA showed that $F_{\mathrm{ST}}$ was significant and most of the total variations were explained by the genetic differences within populations (Table II). The pairwise $F_{\text {ST }}$ 
values of FZW were significantly divergent from the others. FZW was divided from the others in the UPGMA tree (Fig. 3 ). This result was also observed in the haplotype network (Fig. 5), in which most haplotypes of FZW were assembled. The PCoA indicated that only FZW was different from the others. With frequent gene flow and development of the wild populations, the genetic divergence between wild and cultured specimens groups would recede. Several studies on wild and cultured populations have reported similar results (Chen et al., 2016; Jiang et al., 2007; Xiao et al., 2017). However, FZW was significantly different from the other specimens groups, possibly because of geographic factors. For the aquaculture of M. unguiculatus, Zhejiang Province in China is the main production area for mussel juveniles. The spawning season of $M$. unguiculatus is between November and January; at this stage, the planktonic larva is not affected by the Yangtze River plume. Thus, the larvae could spread widely without any barriers, which is consistent with the results obtained by Shen et al. (2009).

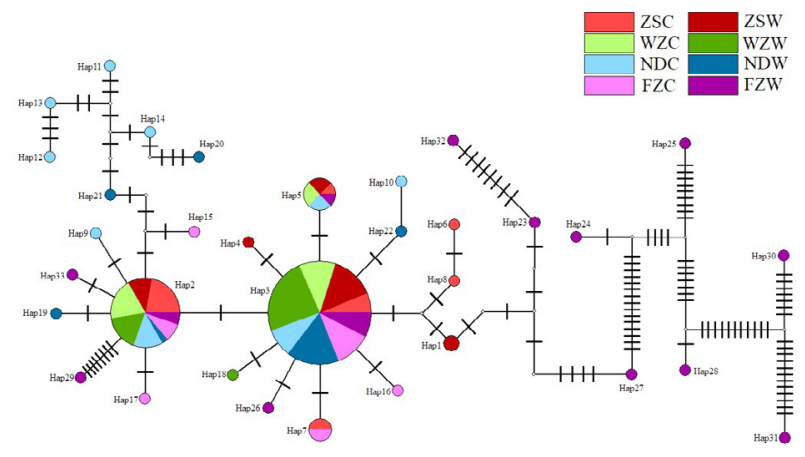

Fig. 5. Haplotype network for the eight specimens of Mytilus unguiculatus. The plot of the haplotype network showed that these haplotypes were gathered into one cluster.

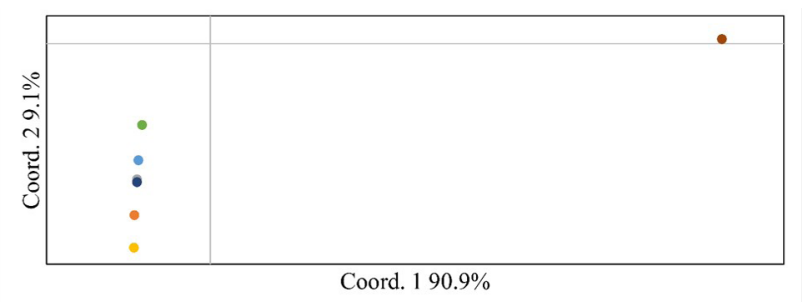

$\bullet \mathrm{ZSW} \bullet \mathrm{ZSC} \bullet \mathrm{WZC} \bullet \mathrm{NDC} \bullet \mathrm{FZC} \bullet \mathrm{WZW} \bullet \mathrm{NDW} \bullet \mathrm{FZW}$

Fig. 6. Principal coordinate analysis of population differentiation on the basis of the 16S rRNA.

\section{Management implications}

Among the cultured specimens groups, high haplotype diversity and low nucleotide diversity indicated that the parents of the cultured specimens groups would be from a single population of M. unguiculatus, and, then, the sample size expanded rapidly. The haplotype number of the cultured specimens groups was less than that of the wild specimens (Fig. 3). Therefore, the cultured specimens groups possibly developed from the natural spat of a single or several wild populations. These results were confirmed using the genetic structure analysis. The gene flow between the cultured and wild specimens groups was low, and most of the pairwise $F_{\mathrm{ST}}$ values were non-significant.

In sessile marine species, a long pelagic larval duration increases the dispersal of the larvae and gene flow between populations over large spatial scales. Usually, a shortened larval duration is linked to frequent gene exchange (Cowen et al., 2009). Remarkably, the ZS and WZ specimens groups were not divergent; this suggested that the wild and cultured specimens groups were crossed. The mussel breeding was evolving without consideration of fisher farmers, causing the confusedly mussel seeding cultivation. The gene exchange in wild populations is obviously affected by human activities. Inbreeding reduces the genetic variation of wild populations and causes a decline in the quality of seeding. Because of traditional farming methods (using a rope or deadman anchor to fix the mussels), the cultured specimens groups travel off the farm and interbreed with wild specimens groups. Artificial movement of animals between sites results in a limited genetic structure (Pérez-Portela et al., 2013). In the absence of distinct genetic protection units, the wild and cultured populations would become more similar, which is why the germplasm resources of $M$. unguiculatus deteriorated in Zhejiang. NDC showed significant differentiation from the other cultured specimens groups, possibly because NDC interbred with the wild specimens groups. This is a sign that the barriers between wild and cultured populations are broken; under the risk of depletion, the wild population in ND may have been assimilated by the cultured mussels.

On the basis of some insights for the maintenance of genetic stock, on-shore farming would be a better substitution model to reduce the number of cultured larvae that sneak into the natural environment because the larvae would be caught by the water filtration system (Appleford et al., 2012). On-shore farming would also be able to easily control the production chain and enhance mussel quality. The genetic information obtained in this study forms the basis for further studies on M. unguiculatus as a seeding resource in aquaculture. Our findings could provide genetic insights for selecting the first generation. Farming practice should reduce the effect of natural habitat of wild populations to insure the wild populations that could keep the primary evolution as a cultured stock with rich genetic variability. As a preventive measure, the farming area should be limited, and genetic diversity levels of the 
cultured and wild populations should be monitored (De Girolamo et al., 2017). Appropriate population management can help to prevent inbreeding and maintain heterozygosity levels and breeding that promote genetic diversity and reduce inbreeding (Barroso et al., 2005). Focus on the genetic protection units is also necessary to ensure the wild populations are not affected by human activities and the cultured organisms are isolated on the basis of international regulations (Diversity, 2010).

\section{CONCLUSION}

In this study, high diversity in cultured specimens groups was estimated than wild groups in hard-shelled mussel, M. unguiculatus. It was suggested to establish genetic protection units for M. unguiculatus.

\section{ACKNOWLEDGEMENTS}

This work was financially supported by the Fundamental Research Funds for Zhejiang Provincial Universities and Research Institutes (Grant No.: 2019J00021), the Natural Science Foundation of Zhejiang Province (Grant No.: LQ18D060004), the Zhoushan technology office program (Grant No.: 2019F12004), theSpecial Fund for the Key Research and Development Project of Zhejiang Province (Grant No.: 2019C02056) and the Open Foundation from Marine Sciences in the First-Class Subjects of Zhejiang Province.

Statement of conflict of interest

The authors have declared no conflict of interest.

\section{REFERENCES}

Aljanabi, S. and Martinez, I., 1997. Universal and rapid salt-extraction of high quality genomicDNA for PCR-based techniques. Nucl. Acids Res., 25: 46924693. https://doi.org/10.1093/nar/25.22.4692

Allendorf, F., 1986. Genetic drift and the loss of alleles versus heterozygosity. Zoo Biol., 5: 181-190. https://doi.org/10.1002/zoo.1430050212

An, H., Jee, Y., Min, K., Kim, B. and Han, S., 2005. Phylogenetic analysis of six species of Pacific abalone (Haliotidae) based on DNA sequences of 16s rRNA and cytochrome c oxidase subunit I mitochondrial genes. Mar. Biotechnol., 7: 373-380. https://doi.org/10.1007/s10126-004-4405-2

Appleford, P., Lucas, J. and Southgate, P., 2012. General principles. Aquacul. Farm. Aquat. Anim. Pl., pp. 11-46.

Barroso, R., Hilsdorf, A., Moreira, H., Cabello, P. and
Traub-Cseko, Y., 2005. Genetic diversityof wild and cultured populations of Brycon opalinus (Cuvier, 1819) (Characiforme, Characidae, Bryconiae) using microsatellites. Aquaculture, 247: 51-65. https://doi.org/10.1016/j.aquaculture.2005.02.004

Chang, K. and Wu, J., 2007. Study on artificial propagation of mussel Mytilus coruscus (in Chinese with English abstract). S. China Fish. Sci., 3: 26-30.

Chen, W., Zhang, F., Wang, J., Wei, H., Jiang, Y., Zhang, H., Ling, J, Cheng, J. and M, L., 2016. Genetic diversity of wild and cultured populations of Larimichthys crocea in the East China Sea and Yellow Sea based on COI sequence (in Chinese with English abstract). J. Fish. Sci. China, 23: 1255-1267.

Cowen, R. and Sponaugle, S., 2009. Larval dispersal and marine population connectivity. Annu. Rev. mar. Sci., 1: 443-466. https://doi.org/10.1146/ annurev.marine.010908.163757

De Girolamo, M., Torboli, V., Pallavicini, A. and Isidro, E., 2017. Genetic diversity and structure of Megabalanus azoricus in the Azores: Implications for aquaculture management. J. Sea Res., 129: 5360. https://doi.org/10.1016/j.seares.2017.09.004

Diversity, S., 2010. Global Biodiversity Outlook 3. Glob. Biodiv. Outl., 5: 267-284.

Earl, D. and Vonholdt, B., 2011. STRUCTURE HARVESTER: a website and program for visualizing STRUCTURE output and implementing the Evanno method. Conserv. Genet. Resour., 4: 359-361. https://doi.org/10.1007/s12686-0119548-7

Evanno, G., Regnaut, S. and Goudet, J., 2005. Detecting the number of clusters of individuals using the software STRUCTURE: A simulation study. Mol. Ecol., 14: 2611-2620. https://doi.org/10.1111/ j.1365-294X.2005.02553.x

Excoffier, L. and Lischer, H., 2010. Arlequin suite ver 3.5: a new series of programs to perform population genetics analyses under Linux and Windows. Mol. Ecol. Resour., 10: 564-567. https://doi.org/10.1111/ j.1755-0998.2010.02847.x

Excoffier, L., Smouse, P. and Quattro, J., 1992. Analysis of molecular variance inferred from metric distances among DNA haplotypes: Application to human mitochondrial DNA restriction data. Genetics, 131: 479-491.

Fao., 2000. Code of conduct for responsible fisheries. Am. Psychol., 20: 1304-1306.

Frankham, R., Ballou, J., Briscoe, D. and Mcinnes, K., 2002. Introduction to conservation genetics. Zool. Afri., 38: 192-192. https://doi.org/10.1017/ 


\section{CBO9780511808999}

Hoffmann, A. and Sgro, C., 2011. Climate change and evolutionary adaptation. Nature, 470: 479-485. https://doi.org/10.1038/nature09670

Jakobsson, M. and Rosenberg, N.A., 2007. CLUMPP: a cluster matching and permutation program for dealing with label switching and multimodality in analysis of population structure. Bioinformatics, 23: 1801-1806. https://doi.org/10.1093/bioinformatics/ btm233

Jiang, Z., Niu, D., Chen, H., Shen, H. and LI, J., 2007. The genetic analysis of ITS-1 and ITS-2 between wild and cultured populations of Sinonovacula constricta in Fujian (in Chinese with English abstract). Mar. Fish., 29: 314-318.

Kahilainen, A., Puurtinen, M. and Kotiaho, J., 2014. Conservation implications of species-genetic diversity correlations. Glob. Ecol. Conserv., 2: $315-$ 323. https://doi.org/10.1016/j.gecco.2014.10.013

Kumar, S., Stecher, G. and Tamura, K., 2016. MEGA7: Molecular evolutionary genetics analysis version 7.0 for bigger datasets. Mol. Biol. Evol., 33: 18701874. https://doi.org/10.1093/molbev/msw054

Larkin, M., Blackshields, G., Brown, N., Chenna, R., Mcgettigan, P., Mcwilliam, H., Valentin, F., Wallace, I., Wilm, A., Lopez, R., Thompson, J., Gibson, T. and Higgins, D., 2007. Clustal W and Clustal X version 2.0. Bioinformatics, 23: $2947-$ 2948. https://doi.org/10.1093/bioinformatics/ btm404

Lundrigan, T.,Reist, J. and Ferguson, M., 2005. Microsatellite genetic variation within and among Arctic charr (Salvelinus alpinus) from aquaculture and natural populations in North America. Aquaculture, 244: 63-75. https://doi.org/10.1016/j. aquaculture.2004.11.027

Lydeard, C., Mulvey, M. and Davis, G., 1996. Molecular systematics and evolution of reproductive traits of North American freshwater unionacean mussels (Mollusca: Bivalvia) as inferred from 16S rRNA gene sequences. Phil. Trans. R. Soc. Lond. B Biol. Sci., 351: 1593-1603. https://doi.org/10.1098/ rstb.1996.0143

O’grady, J., Brook, B., Reed, D., Ballou, J., Tonkyn, D. and Frankham, R., 2006. Realistic levels of inbreeding depression strongly affect extinction risk in wild populations. Biol. Conserv., 133: 4251. https://doi.org/10.1016/j.biocon.2006.05.016

Palumbi, S., 1994. Genetic divergence, reproductive isolation, and marine speciation. Annu. Rev. Ecol. System., 25: 547-572. https://doi.org/10.1146/ annurev.es.25.110194.002555
Pan, B., Wu, Q., Zhang, S., Song, L. and Bu, W., 2006. Molecular phylogeny of Meretrix (Mollusca, Bivalvia) based on 16S rRNA genes and ITS1 sequences (in Chinese with English abstract). Ceanol. Limnol. Sin., 37: 342-347.

Peakall, R. and Smouse, P., 2006. GENALEX 6: genetic analysis in Excel. Population genetic software for teaching and research. Mol. Ecol. Notes, 6: 288-295. https://doi.org/10.1111/j.1471-8286.2005.01155.X

Pérez-Portela, R., Almada, V. and Turon, X., 2013. Cryptic speciation and genetic structure of widely distributed brittle stars (Ophiuroidea) in Europe. Zool. Scrip., 42: 151-169. https://doi.org/10.1111/ j.1463-6409.2012.00573.X

Pritchard, J., Wen, X. and Falush, D., 2009. Documentation for STRUCTURE software: version 2.3. J. Pediat. Surg., 41: 55-63.

Reed, D. and Frankham, R., 2001. How closely correlated are molecular and quantitative measures of genetic variation? A meta-analysis. Evolution, 55: 1095 1103. https://doi.org/10.1111/j.0014-3820.2001. tb00629.x

Rochelle, P.,Fry, J., Parkes, R. and Weightman, A., 1992. DNA extraction for $16 \mathrm{~S}$ rRNA gene analysis to determine genetic diversity in deep sediment communities. Eur. Microbiol. Soc., 100: 5966. https://doi.org/10.1111/j.1574-6968.1992. tb05682.x

Röhl, A. and Mihn, D., 1997. Network: A program package for calculating phylogenetic networks. Paper presented at the Mathematisches Seminar, University of Hamburg, Hamburg.

Rozas, J., Ferrer-Mata, A., Sánchez-Delbarrio, J., Guirao-rico, S., Librado, P., Ramos-onsins, S. and Sánchez-Gracia, A., 2017. DnaSP 6: DNA sequence polymorphism analysis of large data sets. Mol. Biol. Evol., 12: 12. https://doi.org/10.1093/ molbev/msx248

Shen, Y., Li, J. and Feng, B., 2009. Genetic analysis of cultured and wild populations of Mytilus coruscus based on mitochondrial DNA. Zool. Res., 30: 240246. https://doi.org/10.3724/SP.J.1141.2009.03240

Shu, J., Li, Q., Yu, R. and Tian, C., 2008. Microsatellites analysis on genetic variation between wild and cultured populations of pacific abalone (Haliotis discus hannai) (in Chinese with English abstract). Period. Ocean Univ. China, 38: 52-58.

Thanh, H., Liu, Q., Zhao, L., Zhang, H., Liu, J. and Hai, D., 2015. Genetic diversity of cultured populations of giant freshwater prawn (Macrobrachium rosenbergii) in China using mtDNA COI and $16 \mathrm{~S}$ rDNA markers. Biochem. System. Ecol., 62: 261- 
269. https://doi.org/10.1016/j.bse.2015.09.011

Wang, R., Liu, M., Liao, Z., Lu, T., Wu, M. and He, G., 2010. Purification and identification of Mytilins from Mytilus coruscus (in Chinese with English abstract). J. Fish. China, 34: 153-159. https://doi.org/10.3724/ SP.J.1231.2010.06514

Xiao, Q., Liu, Q., Wu, X., Wang, H., Dong, P., Liu, H. and Cheng, Y., 2017. Genetic diversity analysis of wild and cultured Megalopa population of Eriocheir sinensis from Yangtze River (in Chinese with English abstract). Genom. appl. Biol., 5: 260-270.

Xiong, M., Tian, S., Zhang, Z., Fan, D. and Zhang, Z., 2014. Population genetic structure and conservation units of Sinomanglietia glauca (Magnoliaceae) (in Chinese with English abstract). Biodiv. Sci., 22: 476484. https://doi.org/10.3724/SP.J.1003.2014.14017

Xu, M., Jiang, L., Shen, K., Wu, C., He, G. and Hsiao C., 2016. Transcriptome response to copper heavy metal stress in hard-shelled mussel (Mytilus coruscus). Genom. Data, 7: 152-154. https://doi.org/10.1016/j. gdata.2015.12.010

Yang, J., Li, W., Liang, X., Li, Y., Chen, Y., Bao, W. and Li, J., 2014. Effects of adrenoceptor compounds on larval metamorphosis of the mussel Mytilus coruscus. Aquaculture, 426-427: 282-287. https:// doi.org/10.1016/j.aquaculture.2014.02.019

Yang, S., Yang, L., Zhao, D. and Ren, Y., 2015. Resources investigation and evaluation of Mytilus coruscus around Taishan Islands, Fujian (in Chinese with English abstract). Mar. Sci., 39: 32-38.

Yuan, W., Li, C., Jiao, H., Lin, Z. and Bao, Y., 2017. Genetic resources assessment of mussel Mytilus coruscus based on COI gene in Yushan Island (in Chinese with English abstract). Mar. Sci., 41: 107112. 